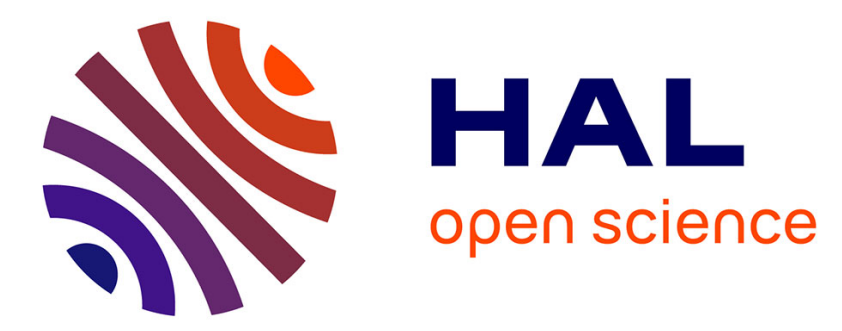

\title{
Study of scale effect in an internal erosion mechanism: centrifuge model and energy analysis
}

Didier Marot, van Duong Le, Josselin Garnier, Luc Thorel, Philippe Audrain

\section{To cite this version:}

Didier Marot, van Duong Le, Josselin Garnier, Luc Thorel, Philippe Audrain. Study of scale effect in an internal erosion mechanism: centrifuge model and energy analysis. European Journal of Environmental and Civil Engineering, 2012, 16 (1), pp.1-19. 10.1080/19648189.2012.667203 . hal-01007342

\section{HAL Id: hal-01007342 \\ https://hal.science/hal-01007342}

Submitted on 12 Dec 2018

HAL is a multi-disciplinary open access archive for the deposit and dissemination of scientific research documents, whether they are published or not. The documents may come from teaching and research institutions in France or abroad, or from public or private research centers.
L'archive ouverte pluridisciplinaire HAL, est destinée au dépôt et à la diffusion de documents scientifiques de niveau recherche, publiés ou non, émanant des établissements d'enseignement et de recherche français ou étrangers, des laboratoires publics ou privés. 


\title{
Study of scale effect in an internal erosion mechanism: centrifuge model and energy analysis
}

\author{
Didier Marot $^{\mathrm{a} *}$, Van Duong Le ${ }^{\mathrm{a}}$, Jacques Garnier ${ }^{\mathrm{b}}$, Luc Thorel ${ }^{\mathrm{b}}$ and Philippe Audrain ${ }^{\mathrm{b}}$ \\ ${ }^{a}$ LUNAM Univ., Institut de Recherche en Génie Civil et Mécanique, F-44600 Saint-Nazaire, \\ France; ${ }^{b}$ LUNAM Univ., IFSTTAR, GER, Physical Modeling in Geotechnics Group, F-44341 \\ Bouguenais, France
}

Suffusion is an internal erosion mechanism, which means detachment and transport
of fine particles within the soil skeleton due to hydraulic seepage flows. Different
researchers have observed that the value of the critical hydraulic gradient required to
initiate suffusion decreases with the length of the specimen tested. A specific centri-
fuge bench was designed to study the suffusion process and to study this scale effect
under a controlled effective stress. Clayey sand specimens were subjected to centri-
fuge acceleration and to a downward flow under a constant hydraulic head. The
study underlines the influence of specimen length on critical hydraulic gradient and
also on the rate of erosion. A new energy analysis of tests is developed, linking the
erosion rate to the power expended by fluid flow, and the eroded clay mass to the
energy dissipation. This method permits the effect of specimen length to be avoided.

La suffusion est un mécanisme d'érosion interne qui correspond au détachement et au transport de particules fines au travers du squelette granulaire sous l'action d'un écoulement. Différents chercheurs ont observé que la valeur du gradient hydraulique critique nécessaire à l'initiation de la suffusion décroît avec la longueur de l'échantillon testé. Un dispositif d'essais en centrifugeuse est spécialement développé afin de caractériser la suffusion et d'étudier cet effet d'échelle sous contrainte effective contrôlée. Des échantillons sablo-argileux sont centrifugés et sont soumis à un écoulement vertical descendant sous charge hydraulique constante. L'étude met en évidence l'influence de la longueur de l'échantillon sur le gradient hydraulique critique et sur le taux d'érosion. Une nouvelle approche énergétique est proposée et permet de relier le taux d'érosion avec la puissance dissipée par le fluide ainsi que la masse érodée avec l'énergie dissipée. Cette approche permet de s'affranchir de l'effet d'échelle.

Keywords: suffusion; scale effect; centrifuge bench; erosion model; energy analysis

Mots-clés: suffusion; effet d'échelle; banc centrifugé; modèle d'érosion; analyse énergétique

\section{Introduction}

Soil grains that form embankments, dams or dykes may be detached and transported under the action of water flow. This process, named internal erosion, may induce the failure of hydraulic earth structures. The two main phenomena of internal erosion in uncracked soils are backward erosion and suffusion (Fell and Fry, 2007). This paper

*Corresponding author. Email: didier.marot@univ-nantes.fr 
deals with suffusion, which concerns only the finer soil fraction. The fine particles are detached and transported through a skeleton constituted by coarser grains.

This complex phenomenon is not well understood and it is characterised by a lack of in situ data that could be used to validate theoretical approaches. An idea was to perform erosion tests on small scale models installed in a geotechnical centrifuge. In order to interpret the test data, it will be necessary to quantify the scaling laws of the suffusion phenomenon, even though the scaling laws have not yet been identified (Garnier et al., 2007).

Several geometric criteria, based on the study of grain size distribution, have been proposed in the literature by Kenney and Lau (1985), Burenkova (1993) and Li and Fannin (2008) among others, with the objective to evaluate the likelihood of suffusion initiation. Wan and Fell (2008) concluded that the most widely used geometric methods are conservative.

Several authors have developed expressions that relate initiation of internal erosion to the critical hydraulic gradient. Skempton and Brogan (1994) postulated that effective stress applied to finer particles is only a part of the effective stress applied to the coarser fraction and they defined the suffusion initiation by a disproportional increase in the velocity of seepage flow. They expressed the difference between classical critical upward hydraulic gradient $i_{c}=\rho^{\prime} / \rho_{w}$ (obtained by Terzaghi's theory) and the critical hydraulic gradient required to initiate suffusion, $i_{c r}$, by:

$$
i_{\mathrm{cr}}=(1-\alpha)\left(\frac{\rho^{\prime}}{\rho_{\mathrm{w}}}\right)
$$

where $\alpha$ is stress reduction factor in the finer fraction (Skempton and Brogan (1994) suggested an order of magnitude less than 0.1 for sandy gravel and its value needed to be determined by internal erosion tests); $\rho^{\prime}$ is submerged unit mass of the soil specimen; and $\rho_{\mathrm{w}}$ is the unit mass of water.

Li (2008) performed suffusion tests on cohesionless soils with a large permeameter (inner diameter: $279 \mathrm{~mm}$ ) and a small permeameter (inner diameter: $102 \mathrm{~mm}$ ). Li (2008) evaluated the suffusion initiation due to a temporal variation of local hydraulic gradient. He observed that the critical hydraulic gradient can be seven times higher with the small permeameter than with the large one for a same type of tested specimen and a same mean vertical effective stress. The difference was attributed to scale effects. From Skempton and Brogan's (1994) concept of stress reduction and with the objective to eliminate this effect, $\mathrm{Li}$ (2008) expressed the critical hydraulic gradient for upward seepage flow, $i_{\mathrm{cr}}$, as a function of normalised vertical effective stress as:

$$
i_{\mathrm{cr}}=\alpha\left(\frac{\sigma_{t 0}^{\prime}}{\rho_{\mathrm{w}} g \Delta z}+\frac{\rho^{\prime}}{\rho_{w}}\right)=\alpha\left(\frac{\sigma_{\mathrm{vm} 0}^{\prime}}{\rho_{\mathrm{w}} g \Delta z}+0.5 \frac{\rho^{\prime}}{\rho_{w}}\right),
$$

where $\sigma_{t 0}^{\prime}$ is the vertical effective stress on the top of specimen at $i=0 ; \Delta z$ is thickness of soil specimen; $g$ is gravity; and $\sigma_{\mathrm{vm} 0}^{\prime}$ is mean vertical effective stress in the middle of soil layer $\left(\sigma_{\mathrm{vm} 0}^{\prime}=\sigma_{t 0}^{\prime}+0.5 \rho^{\prime} g \Delta z\right)$. It can be noted that the thickness of the soil specimen corresponds to the seepage path in the case of a vertical seepage flow.

The value of stress reduction factor $\alpha$ depends on the specimen reconstitution technique used, the grain size distribution and the particle shape. Li (2008) concluded that $\alpha$ is well correlated with the ratio $\frac{d_{85}^{\prime}}{O_{50}}$ 


$$
\alpha=3.85\left(\frac{d_{85}^{\prime}}{O_{50}}\right)-0.616,
$$

where, $d_{85}^{\prime}$ is the representative diameter of the finer fraction $\left(d_{85}^{\prime}\right.$ : sieve size for which $85 \%$ of the weighed fine fraction is finer) and $O_{50}$ is the average capillary tube diameter of the coarser fraction. Li (2008) indicated that the limit between finer and coarser fractions corresponds to the minimum value of the Kenney and Lau's (1985) ratio $H / F$, where $H$ is mass fraction measured between $D$ and $4 D$ and $F$ is mass fraction smaller than $D$.

Kovacs (1981) defined $O_{50}$ by:

$$
O_{50}=4 \frac{n_{\mathrm{c}}}{1-n_{\mathrm{c}}} \frac{D_{\mathrm{h}}^{\mathrm{c}}}{\alpha_{\mathrm{D}}}
$$

where $n_{\mathrm{c}}$ is porosity of the coarse fraction, $D_{\mathrm{h}}^{\mathrm{c}}$ is the Kozeny effective diameter of the coarse fraction and $\alpha_{\mathrm{D}}$ is the shape coefficient ( 6 for rounded particles, 7 to 9 for angular particles).

$D_{\mathrm{h}}^{\mathrm{c}}$ and $n_{\mathrm{c}}$ can be calculated by:

$$
\begin{gathered}
D_{\mathrm{h}}^{\mathrm{c}}=\frac{1}{\sum \frac{\Delta \mathrm{F}_{\mathrm{i}}^{\mathrm{c}}}{\mathrm{D}_{\mathrm{i}}^{\mathrm{c}}}} \\
n_{\mathrm{c}}=n+F_{\mathrm{n}}(1-n),
\end{gathered}
$$

Where $F_{\mathrm{i}}^{\mathrm{c}}$ and $D_{\mathrm{i}}^{\mathrm{c}}$ are the weight and average diameter of grains in the $i$ th interval of the particle size distribution curve of the coarse fraction; $n$ is the porosity of soil; and $F_{\mathrm{n}}$ is the mass percentage of the finer fraction.

Li (2008) defined a hydromechanical path using Equation (2) constituting an envelope of instability onset; and he noted that upward and downward flow tests appeared to be bounded by this same envelope.

For the case of the piping erosion process, Sellmeijer (1988) expressed the limit stress state of a particle at the interface of fluid and particles. The resultant $\mathrm{R}$ of the weight of particle $\mathrm{W}$ and of the force due to hydraulic shear stress $\mathrm{F}_{\mathrm{s}}$ (Figure 1) should be balanced.

Sellmeijer (1988) proposed an expression for the critical hydraulic gradient associated with the limit stress state of a particle as:

$$
i_{\mathrm{cr}}=\frac{\rho_{\mathrm{p}}^{\prime}}{\rho_{\mathrm{w}}} \operatorname{Tan} \Theta \bar{C}\left(1-0.65 \bar{C}^{0.42}\right)
$$

and

$$
\bar{C}=\frac{d}{\beta}\left(\frac{2}{K L}\right)^{1 / 3},
$$

where $\rho_{\mathrm{p}}^{\prime}$ is the submerged unit mass of the particle; $K$ is the intrinsic permeability; $L$ is the length of seepage path; $\beta$ is the drag factor (ratio of area influenced by drag force and particle cross section); and $d$ is the particle diameter ( $d_{65}$ to $d_{75}$, where $d_{65}$ is the sieve size for which $65 \%$ of the weighed soil is finer). 


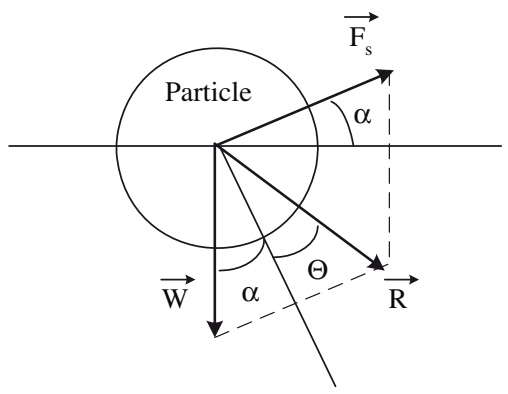

Figure 1. Two force balance of a top particle ( $\alpha$ is the slope of the interface fluid to the particles, and $\Theta$ is the bedding angle).

These values of critical hydraulic gradient (Equations (2) and (7)) are inversely proportional to the length of seepage path, although Sellmeijer's Equation (7) is only as a cubic root of seepage length. Thus, the value of critical hydraulic gradient determined by laboratory tests can be higher by several orders of magnitude than any value determined at real scale. In this context, a question related to the characterisation of internal erosion initiation is whether the use of critical hydraulic gradient approach associated with tests at laboratory scale is efficient or not.

This paper describes a new method of interpretation based on an energy approach for suffusion process. An experimental programme was performed by using the centrifuge modelling technique, to study the suffusion process in reconstituted soil composed of clayey sand. Specimens were centrifuged in order to reproduce full-scale stress states. The results are discussed in terms of influence of length of specimens and ability of the energy analysis to avoid scale effects.

\section{Energy analysis}

The new analysis proposed here is based on a fluid energy dissipation model and this energy is assumed to be transformed into erosion. The energy equation for the fluid in the case of interface erosion was written by Marot et al. (2011).

For the suffusion process, the energy equation is applied between the upstream section A and the downstream section B of the specimen (White, 1999). A volume $V$ of fluid, with a mass $M$ and a density $\rho$, is assumed to have a surface $S$ in contact with the environment (soil and cell). The external surface of the volume is oriented by its normal vector $\vec{n}$ from fluid to environment. The energy equation for the fluid through the specimen can be written by the following equation:

$$
\begin{aligned}
\frac{\mathrm{d} E}{\mathrm{~d} t} & =\frac{\mathrm{d}}{\mathrm{d} t} \iint_{\text {Mass }} \int_{\left(e_{\text {int }}+\frac{w^{2}}{2}+\vec{g} \vec{z}\right) \mathrm{d} M} \\
& =\frac{\partial}{\partial t} \iint_{\text {Volume }} \int_{\text {int }}\left(e+\frac{w^{2}}{2}+\vec{g} \vec{z}\right) \rho \mathrm{dV}+\oint_{S}\left(e_{\text {int }}+\frac{w^{2}}{2}+\vec{g} \vec{z}\right) \rho(\vec{U} \vec{n}) \cdot \mathrm{d} S
\end{aligned}
$$

and

$$
\frac{\mathrm{d} E}{\mathrm{~d} t}=\frac{\mathrm{d} E_{\text {Ther }}}{\mathrm{d} t}+\frac{\mathrm{d} W}{\mathrm{~d} t},
$$


where $t$ is the time, $E_{\text {Ther }}$ is the energy exchange between the system and the environment; $W$ is the mechanical work between the sections $\mathrm{A}$ and $\mathrm{B} ; e_{\text {int }}$ is the internal energy of the fluid; $U$ is the velocity of the fluid, with components $(u, v, w) ; g$ is gravity; and $z$ indicates coordinates.

Three assumptions can be used to simplify the equation. The temperature (isothermal in time) is assumed to be constant on the volume, so the internal energy $\left(e_{\text {int }}\right)$ is assumed constant. The system can be considered as adiabatic, only mechanical work $(W)$ takes place between sections $\mathrm{A}$ and $\mathrm{B}$, which can be expressed by:

$$
\frac{\mathrm{d} E_{\text {Ther }}}{\mathrm{d} t}=0 .
$$

The assumption of a steady state (locally in time) allows the unsteady term of the kinetic energy to be neglected. Finally Equation (9) becomes:

$$
\frac{\mathrm{d} W}{\mathrm{~d} t}=\oint \oint_{S}\left(\frac{w^{2}}{2}+\overrightarrow{\mathrm{g}} \overrightarrow{\mathrm{z}}\right) \rho(\vec{U} \overrightarrow{\mathrm{n}}) \mathrm{d} S .
$$

The total energy dissipation is the sum of energy dissipation by pressure, by erosion at the fluid-solid interface and by viscosity and turbulence in the fluid phase; this latest component is named intra fluid. The dissipation of total energy in the system can be written as:

$$
\frac{\mathrm{d} W}{\mathrm{~d} t}=\frac{\mathrm{d} W_{\text {pressure }}}{\mathrm{d} t}+\frac{\mathrm{d} W_{\text {intrafluid }}}{\mathrm{d} t}+\frac{\mathrm{d} W_{\text {erosion }}}{\mathrm{d} t}
$$

The temporal derivative of work done by pressure, $P$, is defined by:

$$
\frac{\mathrm{d} W_{\text {pressure }}}{\mathrm{d} t}=-\oiint_{S} P(\vec{U} \overrightarrow{\mathrm{n}}) \mathrm{d} S .
$$

Equations (12) to (14) lead to:

$$
\frac{\mathrm{d} W_{\text {intrafluid }}}{\mathrm{d} t}+\frac{\mathrm{d} W_{\text {erosion }}}{\mathrm{d} t}=\oiint_{S}\left(\frac{w^{2}}{2}+\overrightarrow{\mathrm{g}} \overrightarrow{\mathrm{z}}+\frac{P}{\rho}\right) \rho(\vec{U} \overrightarrow{\mathrm{n}}) \mathrm{d} S
$$

The flow conservation with a same specimen section on the whole length leads to assume the same average velocity in the sections A and B. Equation (15) becomes:

$$
\frac{\mathrm{d} W_{\text {Intrafluid }}}{\mathrm{d} t}+\frac{\mathrm{d} W_{\text {erosion }}}{\mathrm{d} t,}=\oiint_{S}\left(\overrightarrow{\mathrm{g}} \vec{z}+\frac{P}{\rho}\right) \rho(\vec{U} \vec{n}) \mathrm{d} S=\rho g \Delta z Q+Q \Delta P,
$$

where $\Delta P=P_{\mathrm{A}}-P_{\mathrm{B}} ; \Delta_{\mathrm{Z}}=Z_{\mathrm{A}}-Z_{\mathrm{B}} ; Q$ is the fluid flow rate.

The Reynolds number can be defined by:

$$
R e=\frac{\rho \bar{U} O_{50}}{\mu},
$$

where $\bar{U}$ is the mean velocity in the pore, $O_{50}$ is the average capillary tube diameter of the coarser fraction and $\mu$ is the dynamic viscosity. 
In the case of the suffusion process, the value of the Reynolds number is relatively low. Thus it is assumed that the dissipation of energy is mainly transformed into erosion and the dissipation intra fluid is neglected. In consequence, the temporal derivative of mechanical work through erosion can be expressed by:

$$
\frac{\mathrm{d} W_{\text {erosion }}}{\mathrm{d} t}=\rho g \Delta z Q+Q \Delta P .
$$

with $\Delta z>0$ if the flow is in downward direction, $\Delta z<0$ if the flow is upward and the temporal derivative of erosion work is equal to $Q \Delta P$ if the flow is horizontal.

For convenience, the temporal derivative mechanical work by erosion is named erosion power. The energy dissipation is the temporal integration of the instantaneous erosion power for the test duration.

\section{Centrifuge tests}

Physical modelling with a centrifuge, a widespread technique in the geotechnical field (Corté, 1988; Kimura, Kusakabe, \& Takemura, 1998; Ko and McLean, 1991; Leung, Lee, \& Tan, 1994; Ng, Zhang, \& Wang, 2006; Phillips, Guo, \& Popescu, 2002; Springman, Laue, \& Seward 2010), makes it possible to reproduce in situ stresses in a small scale model. The full-scale geotechnical model, named prototype $(\mathrm{P})$ and the small scale model (M) are linked together through scaling laws, deduced from equilibrium equations. The main scaling factors $X^{*}=X_{\mathrm{M}} / X_{\mathrm{P}}$ used in this study are listed in Table 1 , in which $N$ is the centrifuge acceleration or 'g-level'.

\subsection{Experimental device}

The device comprises a rigid wall cylinder cell, a hydraulic control system and an effluent sampling system. With the objective of reproducing full-scale stress states, the whole device is placed in the IFSTTAR centrifuge swinging basket (Figure 2).

A schematic diagram of the apparatus is shown in Figure 3. A downward seepage flow is applied to the small scale model under a constant hydraulic head $H_{\mathrm{w}}$ M (origin $=$ bottom of specimen). The hydraulic control system is composed of a tank with a 245 $\mathrm{mm}$ inner diameter, an overflow and a continuing water supply. The fluid circulates into the top of the small scale model using a layer of glass beads to diffuse the fluid uniformly on the specimen contact interface. The small scale model may have different heights, $\Delta z_{\mathrm{M}}$, and at the bottom of the specimen, the funnel-shaped draining system is designed to allow the transport of eroded particles. A wire mesh with a $0.1 \mathrm{~mm}$ pore opening size is placed under the specimen in order to allow only the migration of fine particles.

Table 1. Scaling factors (Garnier et al. 2007).

\begin{tabular}{lc}
\hline Parameter & Scaling factor \\
\hline Length, displacement & $l^{*}=1 / N$ \\
Density & $\rho^{*}=1$ \\
Acceleration & $g^{*}=N$ \\
Stress & $\sigma^{*}=1$ \\
\hline
\end{tabular}




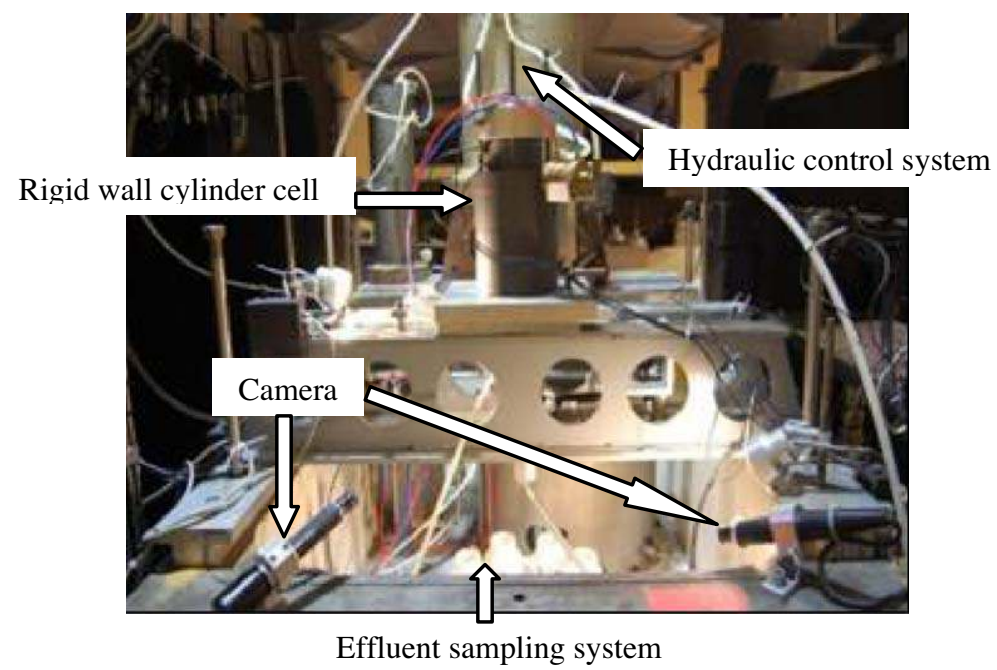

Figure 2. General view of the IFSTTAR centrifuge bench.

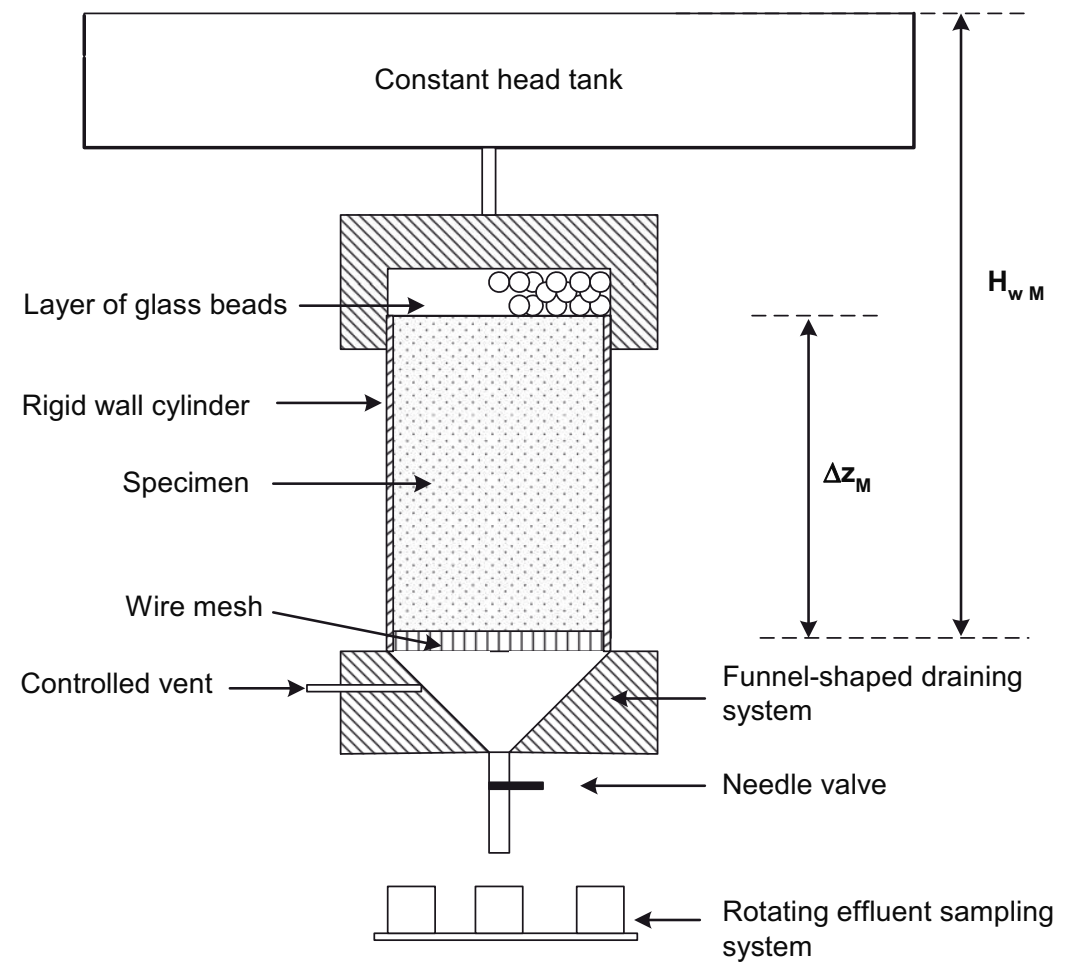

Figure 3. Schematic diagram of down flow seepage test apparatus.

The cell outlet is connected with an effluent sampling system by a drainage pipe and a needle valve. This type of gate is chosen to enable opening even under high 


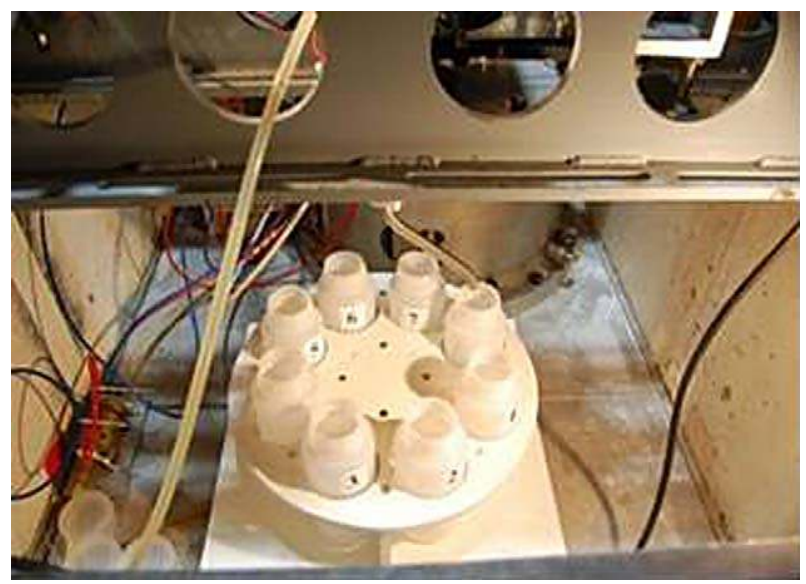

Figure 4. View of the rotating effluent sampling system.

gravity. After the first proof tests, the draining system was equipped with a controlled vent, which avoids the generation of a depression in the specimen induced by the outlet valve opening. The opening of upstream and downstream valves is achieved in flight when the selected centrifuge acceleration is reached.

A rotating system is developed to perform a sampling of the effluent during the test duration (Figure 4) and it is controlled remotely from the centrifuge operator's room through a camera.

\subsection{Tested materials and specimen preparation}

The material tested was a mixture composed of $90 \%$ of Fontainebleau sand and $10 \%$ of clay. The washed Fontainebleau sand has grain density of $26.5 \mathrm{kN} \mathrm{m}^{-3}$ and a grain size distribution within the range $0.1 \mathrm{~mm}$ to $0.4 \mathrm{~mm}$ (uniformity coefficient $=1.33, d_{50}=$ $207 \mu \mathrm{m}$ ). The clay is kaolinite Speswhite (grain density: $26.5 \mathrm{kN} \mathrm{m}^{-3}$ ) and its chemical composition (chemical analysis by $\mathrm{X}$-ray fluorescence, provided by the supplier) is $\mathrm{SiO}_{2}: 43 \%$ and $\mathrm{Al}_{2} \mathrm{O}_{3}: 38 \%$. Without deflocculation, its grain size distribution was measured between $0.5 \mu \mathrm{m}$ and $0.125 \mathrm{~mm}$ (uniformity coefficient $=6, d_{50}=7 \mu \mathrm{m}$ ). Figure 5 plots the grain size distribution of clay, sand and clayey sand (uniformity coefficient $=$ $\left.2.49, d_{50}=195 \mu \mathrm{m}\right)$.

The sand is first mixed with a water content of $8 \%$. Powder clay is added progressively while mixing continues. The mixture is left for 24 hours (at least) in a plastic bag in order to improve the moisture homogeneity. Specimens are prepared by compaction in $73 \mathrm{~mm}$ diameter cells. The reduced scale model height is within a range from $60 \mathrm{~mm}$ to $120 \mathrm{~mm}$. For $60 \mathrm{~mm}$ height, the compaction is made in six layers of 25 blows with a mini Proctor rammer. The average value of the specimens' submerged unit mass was $1.20 \mathrm{~g} \mathrm{~cm}^{-3}$ (maximum relative variation of $\pm 4 \%$ ). The saturation phase begins by an injection of carbon dioxide at the base of the specimen. Saturation is completed in upward direction by using demineralised and deaerated water.

The saturated specimens are then subjected to a centrifuge acceleration with a value g-level $N$ between 10 and 40. A constant hydraulic head is applied at the top of small 


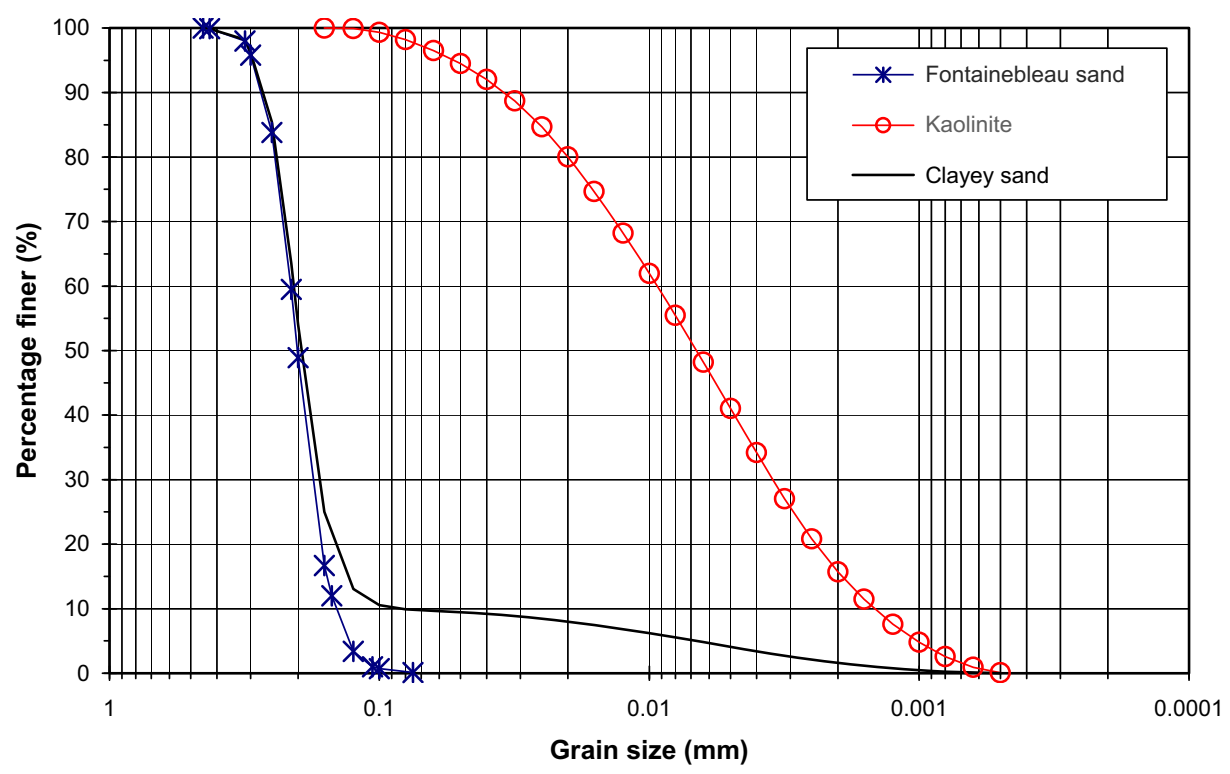

Figure 5. Grain size distribution of tested materials (by laser diffraction particle size analyser).

scale model during the centrifugation, by using demineralised and deaerated water. The hydraulic gradient is determined by:

$$
i=\frac{H_{\mathrm{WM}} N}{\Delta z_{\mathrm{M}}}
$$

The in-flight effective vertical stress at the base of the specimen is calculated by the following equation:

$$
\sigma^{\prime}=\rho^{\prime} N g \Delta z_{\mathrm{M}}
$$

\subsection{Testing programme and typical results}

Twenty tests were performed. For each test performed, Table 2 indicates the value of the reduced scale model height, the value of centrifuge acceleration factor and test duration. The tests end when the maximum volume of effluent that can be collected by the effluent sampling system is reached. Applied hydraulic gradient and effective vertical stress are determined by equations (19) and (20), respectively.

The rate of erosion is expressed by:

$$
m^{\bullet}=\frac{m_{\text {erodedclay }}(t)}{S t},
$$

where $m_{\text {erodedclay }}(t)$ is the dry mass of eroded clay collected during time $t ; S$ is the specimen cross section; and $t$ is the time for collecting the dry mass of eroded clay $m_{\text {erodedclay }}(t)$. 
Table 2. Main characteristics of the tests.

\begin{tabular}{cccccc}
\hline $\begin{array}{c}\text { Number of } \\
\text { specimen }\end{array}$ & $\begin{array}{c}\text { Reduced scale } \\
\text { model height } \Delta z_{\mathrm{M}} \\
(\mathrm{mm})\end{array}$ & $\begin{array}{c}\text { Centrifuge } \\
\text { acceleration factor } \\
N(\mathrm{~g})\end{array}$ & $\begin{array}{c}\text { Hydraulic } \\
\text { gradient } i \\
\left(\mathrm{~m} \mathrm{~m}^{-1}\right)\end{array}$ & $\begin{array}{c}\text { Effective } \\
\text { vertical stress } \\
(\mathrm{kPa})\end{array}$ & $\begin{array}{c}\text { Test } \\
\text { duration } \\
(\mathrm{s})\end{array}$ \\
\hline 1 & 90 & 40 & 130 & 42.5 & 3413 \\
2 & 90 & 26.7 & 76.7 & 28.3 & 6635 \\
3 & 90 & 13.4 & 33.4 & 14.2 & 7985 \\
4 & 120 & 30 & 120 & 42.5 & 6635 \\
5 & 120 & 20 & 70 & 28.3 & 7549 \\
6 & 120 & 10 & 30 & 14.2 & 6446 \\
7 & 60 & 40 & 90 & 28.3 & 7232 \\
8 & 90 & 13.3 & 90 & 28.3 & 1658 \\
9 & 90 & 20 & 45 & 14.2 & 6113 \\
10 & 60 & 20 & 45 & 14.2 & 7233 \\
11 & 120 & 10 & 90 & 28.3 & 3957 \\
12 & 120 & 30 & 45 & 14.2 & 4920 \\
13 & 120 & 26.7 & 150 & 42.5 & 881 \\
14 & 90 & 26.7 & 45 & 28.3 & 3485 \\
15 & 90 & 26.7 & 90 & 28.3 & 1901 \\
16 & 90 & 20 & 150 & 28.3 & 910 \\
17 & 60 & 30 & 150 & 14.2 & 686 \\
18 & 120 & 30 & 45 & 42.5 & 3673 \\
19 & 120 & 20 & 90 & 42.5 & 2452 \\
20 & 120 & 45 & 28.3 & 4937 \\
\hline
\end{tabular}

Typical test results (tests number 14, 15 and 16) are shown in Figure 6 in terms of the temporal evolution with the model time of erosion rate for a value smaller than (a) $2 \mathrm{~g} \mathrm{~s}^{-1} \mathrm{~m}^{-2}$ and (b) $0.2 \mathrm{~g} \mathrm{~s}^{-1} \mathrm{~m}^{-2}$. These three tests are performed with reduced scale model height of $90 \mathrm{~mm}$ and applied effective stress of $28.3 \mathrm{kPa}$. Each point of the graph is deduced from delayed analysis of the fluid taken in a bottle of the sampling system.

In a few minutes, the rate of erosion increased sharply to reach a maximum value, which is higher with a high value of hydraulic gradient (maximum erosion rate is 1.71 $\mathrm{g} \mathrm{s}^{-1} \mathrm{~m}^{-2}, 0.16 \mathrm{~g} \mathrm{~s}^{-1} \mathrm{~m}^{-2}$ and $0.04 \mathrm{~g} \mathrm{~s}^{-1} \mathrm{~m}^{-2}$ for a hydraulic gradient equal to $150 \mathrm{~m}$ $\mathrm{m}^{-1}, 90 \mathrm{~m} \mathrm{~m}^{-1}$ and $45 \mathrm{~m} \mathrm{~m}^{-1}$, respectively). The increase of erosion rate was followed by a rapid decrease with time (erosion rate is near zero at $t=180 \mathrm{~s}, t=460 \mathrm{~s}$, and $t=$ $850 \mathrm{~s}$ for specimen numbers 16,15 and 14 , respectively).

The eroded clay mass in each bottle of the sampling system can be neglected in comparison with the injected water mass. Thus, flow rate and finally hydraulic conductivity, $k$, are calculated from the measurement of duration to fill up each bottle. The evolution of hydraulic conductivity with time is plotted in Figure 7. The initial hydraulic conductivity was about $10^{-5} \mathrm{~m} \mathrm{~s}^{-1}$ and it decreased with time. The minimal value of hydraulic conductivity occurred well after the maximum value of erosion rate was observed. Thus, as previously described by Reddi, Lee and Bonala (2000) and Marot, Bendahmane, Rosquoet and Alexis (2009), the decrease of hydraulic conductivity during suffusion can be attributed to particle redeposition and clogging processes within the specimen. It can be assumed that the flow path first induces a detachment and a transport of clay particles through a phenomenon of suffusion. A part of detached clay particles is collected downstream of the specimen but another part of detached particles is filtrated within the specimen. This filtration induces a clogging and finally the decrease of the hydraulic conductivity. 


\section{Discussion}

\subsection{Influence of specimen length on hydraulic gradient approach}

Figure 8 shows the maximum value of erosion rate versus the hydraulic gradient. The maximum erosion rate (expressed in $\mathrm{g} \mathrm{s}^{-1} \mathrm{~m}^{-2}$ ) seems to be related to hydraulic gradient by a power law, which is expressed by:

$$
m_{\max }^{\bullet}=2.710^{-3}\left(10^{0.02 i}-1\right)
$$

The comparison of the maximum values of erosion rate calculated by equation (22) and the measurements leads to a correlation coefficient $R^{2}=0.86$. This relationship con-

(a)

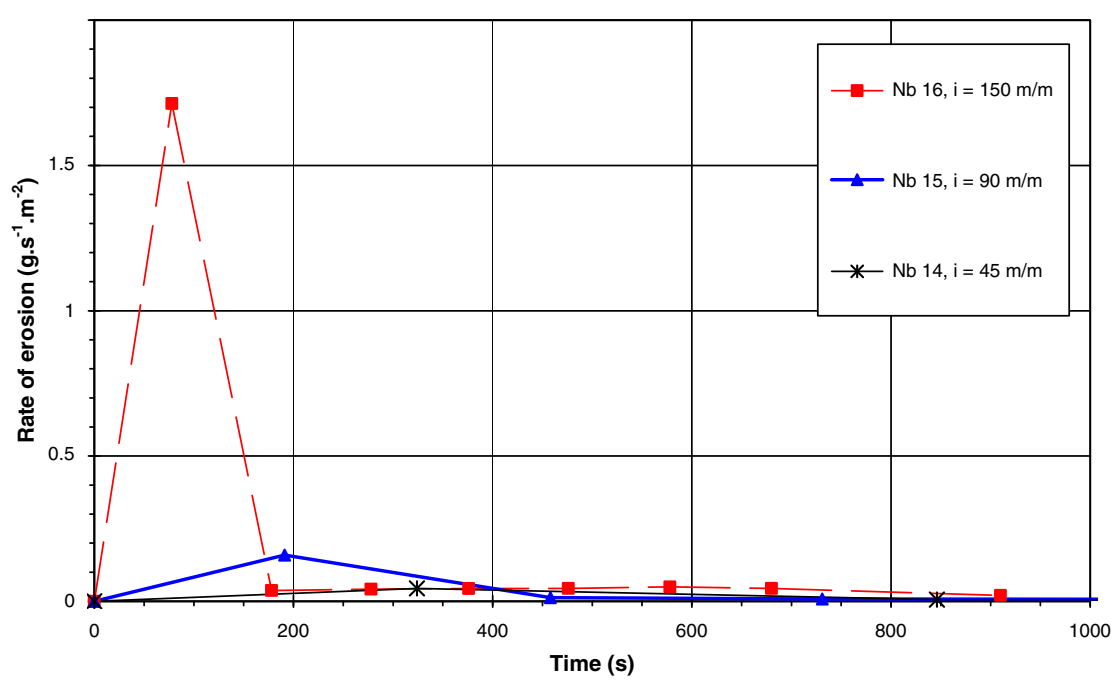

(b)

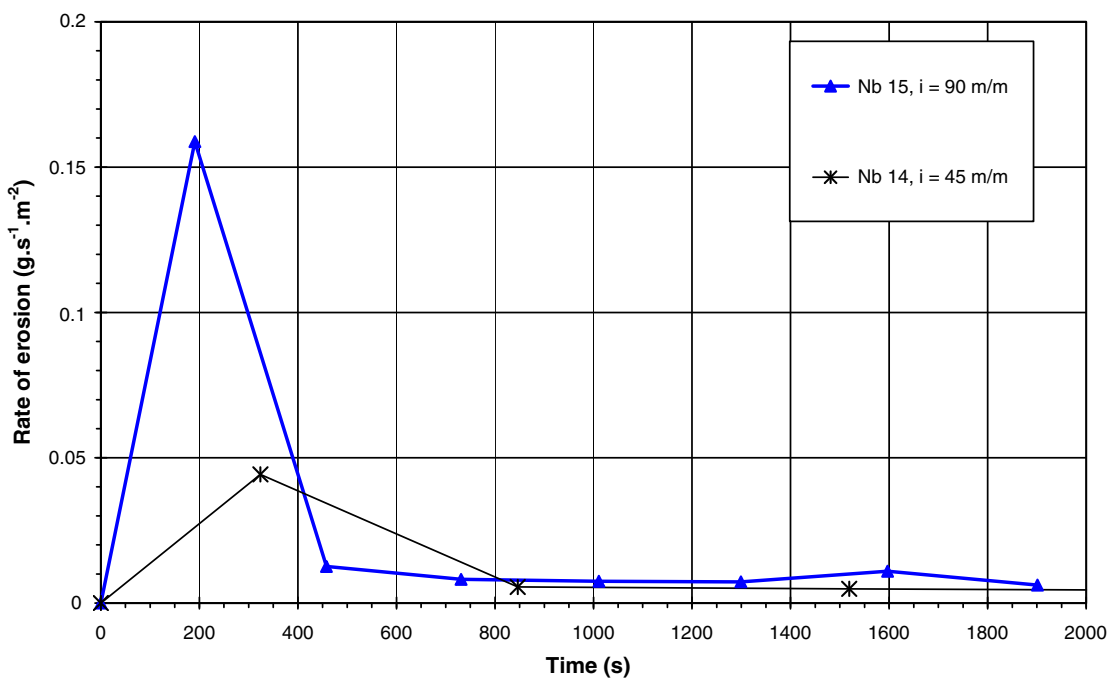

Figure 6. Rate of erosion versus time for (a) high values of erosion rate and (b) erosion rate smaller than $0.2 \mathrm{~g} \mathrm{~s}^{-1} \mathrm{~m}^{-2}$. 


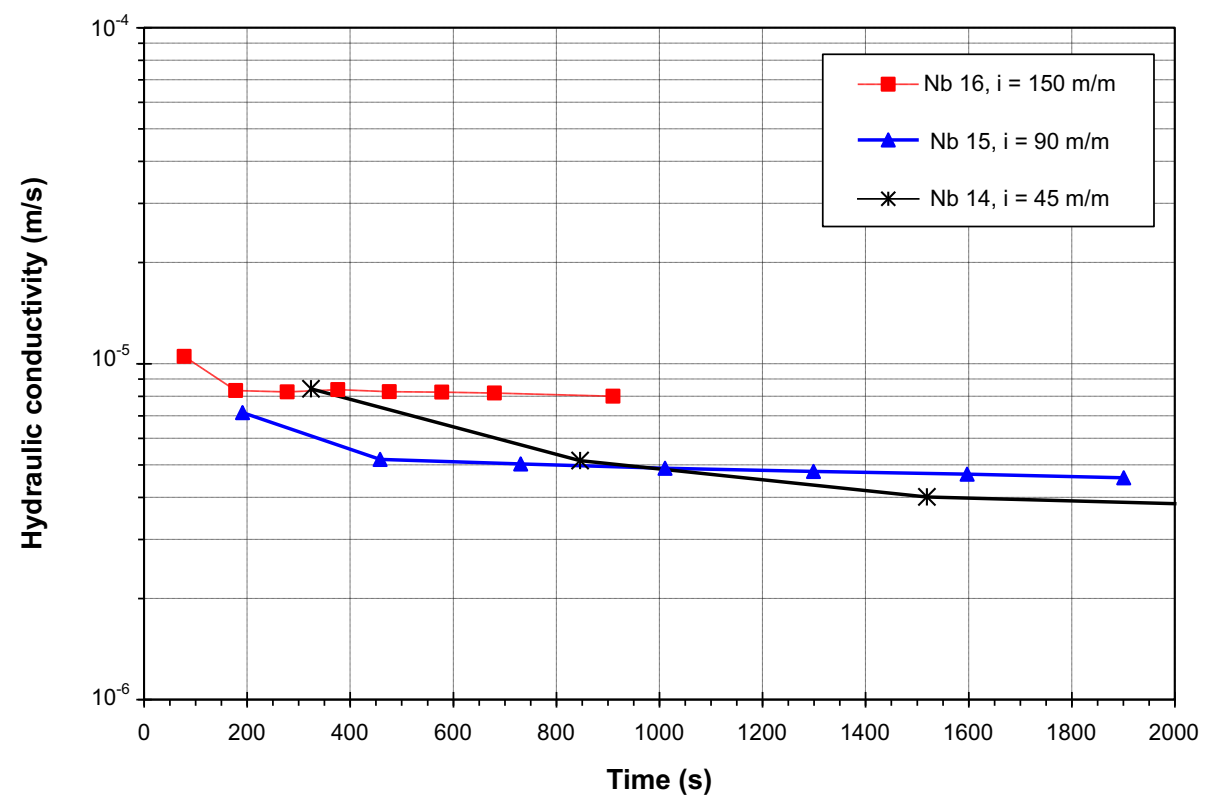

Figure 7. Hydraulic conductivity versus time.

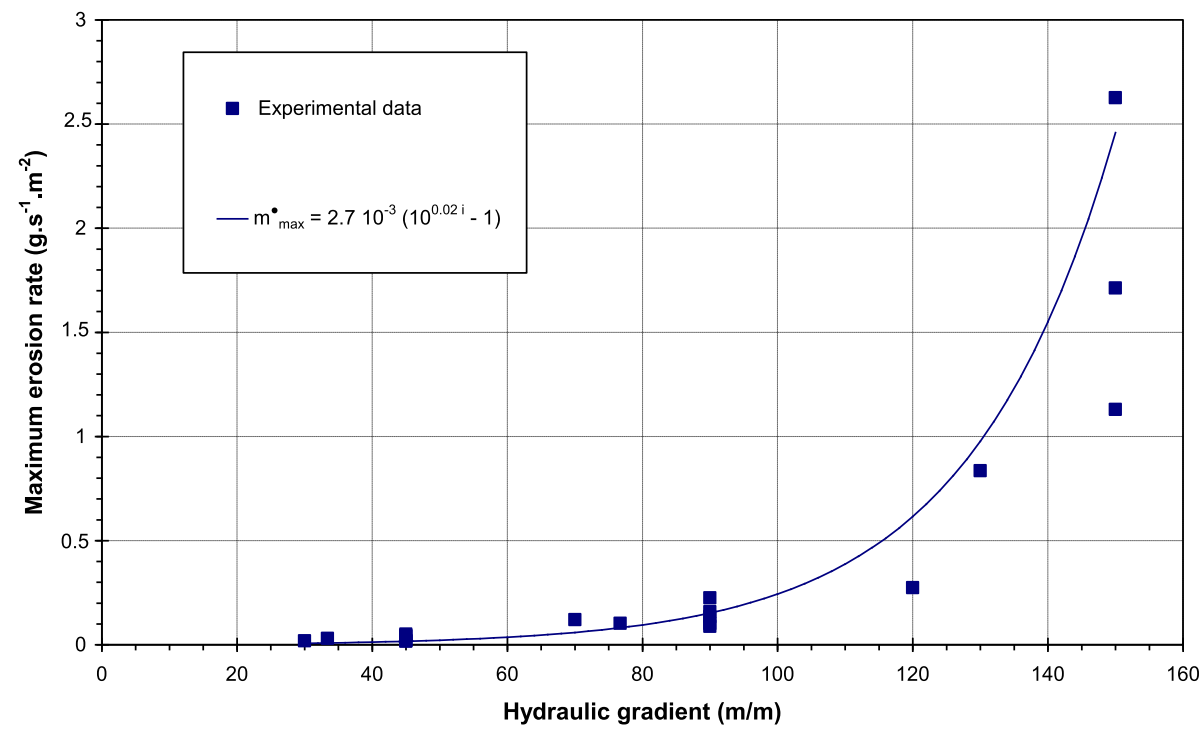

Figure 8. Maximum erosion rate versus hydraulic gradient.

firms the power law proposed by Bendahmane, Marot and Alexis (2008) for clay suffusion with another type of clayey sand. However, no unique relation seems to exist and the erosion rate can double for the same value of hydraulic gradient (for example $90 \mathrm{~m}$ $\mathrm{m}^{-1}$ or $150 \mathrm{~m} \mathrm{~m}^{-1}$ ). 
(a)

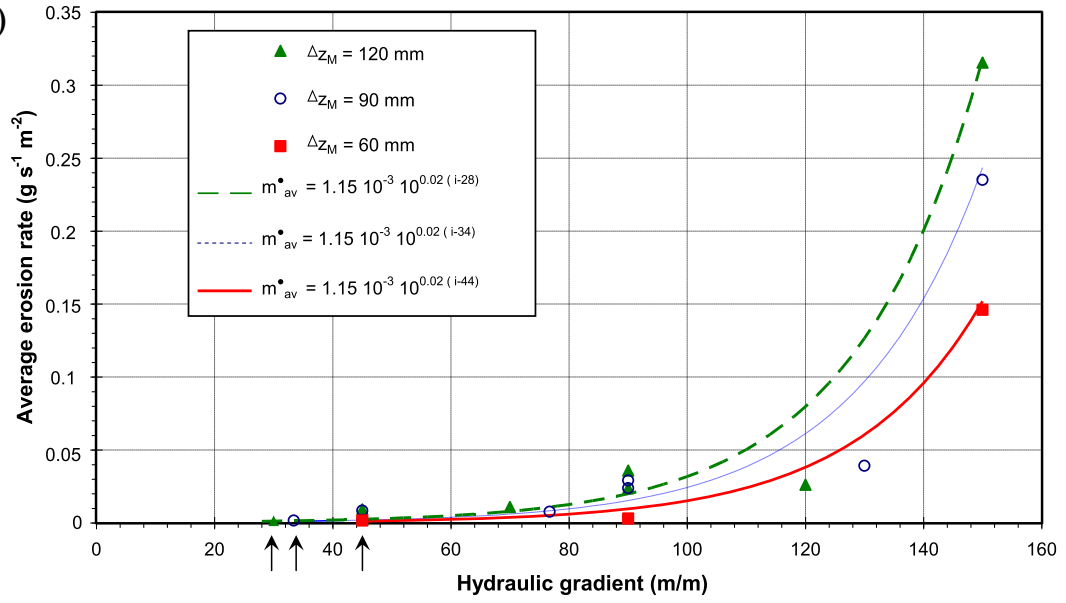

(b)

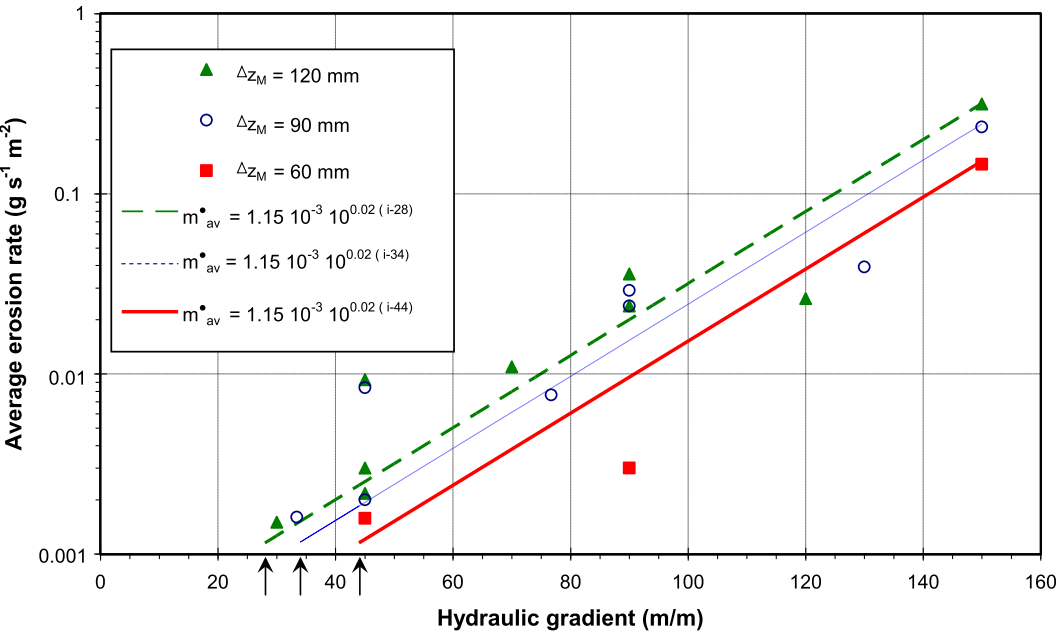

Figure 9. Average erosion rate versus hydraulic gradient and reduced scale model height: (a) linear scale and (b) logarithmic scale.

The average erosion rate $m_{a v}$ is determined by the ratio of total dry mass of eroded clay to test duration and specimen cross section. Variations of average erosion rate with hydraulic gradient are plotted in Figure 9(a) with a linear scale and in Figure 9(b) with a logarithmic scale in order to improve the readability of the low values of average erosion rate. In this study, the onset of suffusion is evaluated on the detection of eroded particles in effluent. Thus the critical value of hydraulic gradient is associated with the ability to detect the erosion. The accuracies of mass, test duration and diameter cell measurements are estimated: $1 \mathrm{mg}, 1 \mathrm{~s}$ and $1 \mathrm{~mm}$ respectively. The calculation of the corresponding accuracy of the average erosion rate leads to $1.1510^{-3} \mathrm{~g} \mathrm{~s}^{-1} \mathrm{~m}^{-2}$. Thus the critical value of hydraulic gradient corresponds to this minimum value of erosion rate measurement. A correlation between average erosion rate and hydraulic gradient can be established as a function of reduced scale model height $\Delta z_{\mathrm{M}}$. For $\Delta z_{\mathrm{M}}=60 \mathrm{~mm}$, $\Delta z_{\mathrm{M}}=90 \mathrm{~mm}$ and $\Delta z_{\mathrm{M}}=120 \mathrm{~mm}$ the correlations can be expressed by Equations (23), (24) and (25), respectively: 


$$
\begin{array}{ll}
m_{a v}^{\bullet}=1.1510^{-3} 10^{0.02(i-44)} & \left(R^{2}=0.99\right) \\
m_{a v}^{\bullet}=1.1510^{-3} 10^{0.02(i-34)} & \left(R^{2}=0.93\right) \\
m_{a v}^{\bullet}=1.1510^{-3} 10^{0.02(i-28)} & \left(R^{2}=0.96\right)
\end{array}
$$

Thus the critical hydraulic gradient to initiate suffusion decreases with the reduced scale model height: $i_{c r}=44 \mathrm{~m} \mathrm{~m}^{-1}$ for $\Delta_{z M}=60 \mathrm{~mm}, i_{c r}=34 \mathrm{~m} \mathrm{~m}^{-1}$ for $\Delta z_{M}=90$ $\mathrm{mm}$ and $i_{c r}=28 \mathrm{~m} \mathrm{~m}^{-1}$ for $\Delta z_{M}=120 \mathrm{~mm}$. These values of critical hydraulic gradient are indicated by arrows in Figure 9.

The critical value of the hydraulic gradient can be determined by Li's (2008) approach. The stress reduction factor $\alpha$ is determined for the clayey sand by using Equations (3) to (6): $\alpha=0.96$ (with $n=0.29, D_{\mathrm{h}}^{\mathrm{c}}=0.22 \mathrm{~mm}, O_{50}=0.06 \mathrm{~mm}, d^{\prime}{ }_{85}=$ $0.03 \mathrm{~mm}$ ). The critical hydraulic gradient is calculated by Equation (2) with mean vertical effective stress in the middle of soil layer $\sigma_{v m 0}^{\prime}=0.5 \sigma^{\prime}$ ( $\sigma^{\prime}$ in-flight effective vertical stress at the base of the specimen is determined by Equation (20)).

Table 3 indicates the value of the critical hydraulic gradient for each value of model height $\Delta z_{\mathrm{M}}$, as a function of values of mean vertical effective stress in the middle of soil layer.

These calculated values are systematically smaller than the measured critical gradient values. Tested specimens contain clay and this characteristic can explain the difference between measurements and values that are calculated with an expression defined for cohesionless soils.

The ratio of measured values of critical hydraulic gradient is $i_{c r 120 \mathrm{~mm}} / i_{c r 60 \mathrm{~mm}}=28 / 44=0.64$ for an increase of reduced scale model height from 60 $\mathrm{mm}$ to $120 \mathrm{~mm}$. Li's (2008) approach leads to a ratio of calculated critical hydraulic gradients equal to 0.50 , within the same range of reduced scale model height.

Critical hydraulic gradient for piping can be determined with Sellmeijer's (1988) criteria (Equations (7) and (8)). A set of values of parameters can be chosen, with bedding angle $\Theta=54^{\circ}$, normalised intrinsic permeability for clayey sand $K / d^{2}=0.0045$, and drag factor $\beta=4$. The particle diameter is chosen equal to $d_{70}$ of tested clayey sand, thus $d=230 \mu \mathrm{m}$. The ratio of the values of critical hydraulic gradient is $i_{c r 120 \mathrm{~mm}} / i_{c r 60 \mathrm{~mm}}=0.82$.

Table 3. Values of critical hydraulic gradient calculated by Li's (2008) expression as a function of model height and mean vertical effective stress.

\begin{tabular}{ccc}
\hline $\begin{array}{c}\text { Model height } \Delta z_{\mathrm{M}} \\
(\mathrm{mm})\end{array}$ & $\begin{array}{c}\text { Mean vertical effective stress } \\
(\mathrm{kPa})\end{array}$ & $\begin{array}{c}\text { Critical hydraulic gradient } \\
i_{\mathrm{cr} 0}\end{array}$ \\
\hline 60 & 21.3 & 35 \\
60 & 14.2 & 24 \\
60 & 7.1 & 12 \\
90 & 21.3 & 24 \\
90 & 14.2 & 16 \\
90 & 7.1 & 8 \\
120 & 21.3 & 18 \\
120 & 14.2 & 12 \\
120 & 7.1 & 6 \\
\hline
\end{tabular}




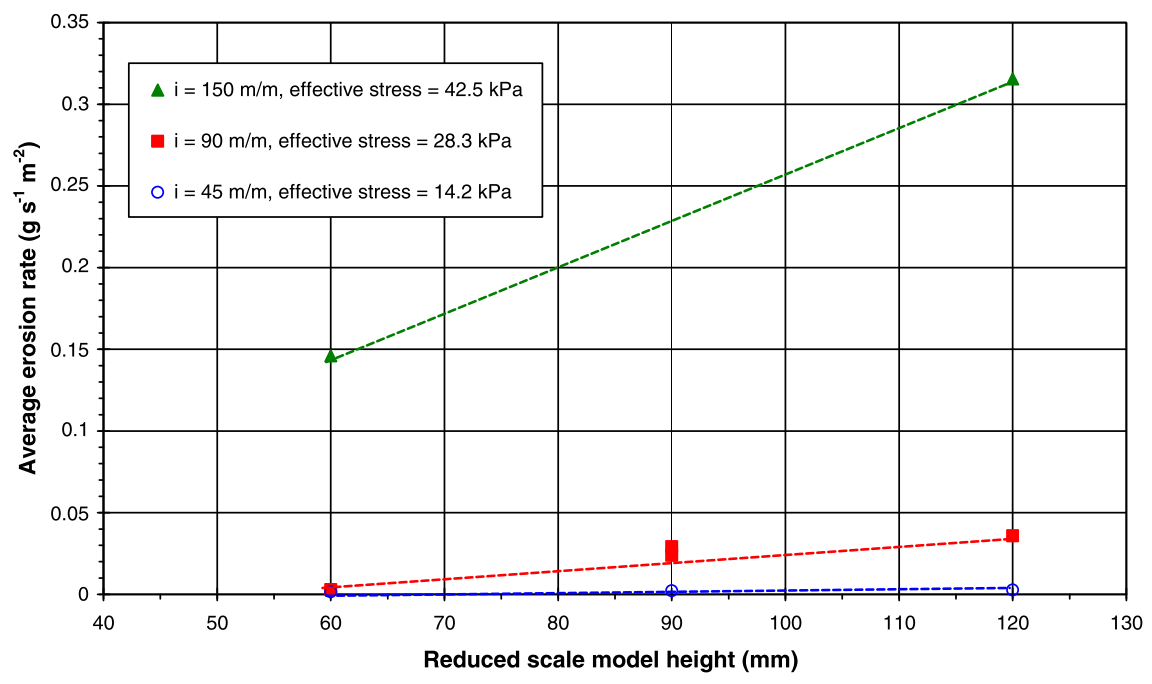

Figure 10. Average erosion rate versus reduced scale model height.

Finally, for an increase of reduced scale model height from $60 \mathrm{~mm}$ to $120 \mathrm{~mm}$, the magnitude of decrease of measured critical hydraulic gradient is between the decrease magnitude calculated with the criteria of Li (2008) and Sellmeijer (1988).

In order to study the scale effect on development of suffusion, Figure 10 shows the average erosion rate versus the reduced scale model height for a same value of hydraulic gradient and the same effective stress at the bottom of specimen.

For the three values of applied effective vertical stress, rate of erosion increases with reduced scale model height. For an increase of reduced scale model height from $60 \mathrm{~mm}$ to $120 \mathrm{~mm}$ and under a hydraulic gradient of $150 \mathrm{~m} \mathrm{~m}^{-1}$, the rate of erosion may be doubled. Thus the scale effect seems to influence both initiation and development of suffusion.

\subsection{Tests analysis by energy approach}

The Reynolds number is calculated by Equation (17) with the higher value of hydraulic gradient $i=150 \mathrm{~m} \mathrm{~m}^{-1}$, initial value of hydraulic conductivity $k=10^{-5} \mathrm{~m} \mathrm{~s}^{-1}$, mean velocity in the pore $\bar{U}=k i / n_{c}=4.210^{-3} \mathrm{~m} \mathrm{~s}^{-1}$, average capillary tube diameter of the coarser fraction $O_{50}=0.06 \mathrm{~mm}$, and dynamic viscosity $\mu=10^{-3} \mathrm{~Pa} \mathrm{~s}$. The obtained value is low, $R e=0.25$, indicating laminar flow and allowing verification of the hypothesis of negligible intra fluid dissipation.

The interpretation of data tests is performed in two steps. In a first step, by using Equation (18), the value of erosion power is determined for each bottle of effluent with, $P_{\mathrm{A}}=\rho_{\mathrm{w}} g N\left(H_{\mathrm{w} \mathrm{M}}-\Delta z_{\mathrm{M}}\right)$ and $P_{\mathrm{B}}=0$. Then, the average value of erosion power is calculated for each test. In a second step, the energy dissipated during the filling up of each bottle of effluent is calculated by the multiplication of corresponding erosion power with duration. Finally, the total energy, $E$, dissipated by fluid flow during a test can be determined by the summation of energy dissipated for each effluent bottle. Table 4 indicates values of average erosion rate, eroded clay mass, average erosion power and total energy dissipation for tests. 
Table 4. Main results of energy analysis.

\begin{tabular}{ccccc}
\hline $\begin{array}{c}\text { Number of } \\
\text { specimen }\end{array}$ & $\begin{array}{r}\text { Average erosion rate } \\
\left(\mathrm{g} \mathrm{s}^{-1} \mathrm{~m}^{-2}\right)\end{array}$ & $\begin{array}{c}\text { Eroded clay } \\
\text { mass }(\mathrm{g})\end{array}$ & $\begin{array}{c}\text { Average erosion } \\
\text { power }(\mathrm{W})\end{array}$ & $\begin{array}{c}\text { Total energy } \\
\text { dissipation }(\mathrm{J})\end{array}$ \\
\hline 1 & 0.039 & 0.56 & 0.26 & 427.29 \\
2 & 0.008 & 0.21 & 0.05 & 209.55 \\
3 & 0.002 & 0.07 & 0.01 & 74.24 \\
4 & 0.026 & 0.73 & 0.12 & 445.37 \\
5 & 0.011 & 0.35 & 0.05 & 252.36 \\
6 & 0.002 & 0.06 & 0.02 & 127.00 \\
7 & 0.003 & 0.09 & 0.04 & 108.55 \\
8 & 0.029 & 0.20 & 0.18 & 208.49 \\
9 & 0.002 & 0.06 & 0.02 & 60.46 \\
10 & 0.002 & 0.05 & 0.01 & 40.01 \\
11 & 0.036 & 0.59 & 0.10 & 386.33 \\
12 & 0.003 & 0.05 & 0.03 & 110.42 \\
13 & 0.316 & 1.16 & 0.85 & 663.59 \\
14 & 0.008 & 0.12 & 0.03 & 101.69 \\
15 & 0.024 & 0.19 & 0.16 & 208.22 \\
16 & 0.235 & 0.67 & 0.72 & 489.01 \\
17 & 0.146 & 0.42 & 0.49 & 331.53 \\
18 & 0.002 & 0.03 & 0.07 & 93.59 \\
19 & 0.024 & 0.24 & 0.17 & 221.80 \\
20 & 0.009 & 0.19 & 0.03 & 108.67 \\
\hline
\end{tabular}

Figure 11 shows the average rate of erosion versus the average erosion power. The linear increase of the average erosion rate (expressed in $\mathrm{g} \mathrm{s}^{-1} \mathrm{~m}^{-2}$ ) according to the average erosion power (expressed in $\mathrm{W}$ ) can be estimated by:

$$
m_{\mathrm{av}}^{\bullet}=0.3504\left(\frac{\mathrm{d} W_{\text {erosion }}}{\mathrm{d} t}\right)_{\mathrm{av}}\left(R^{2}=0.97\right)
$$

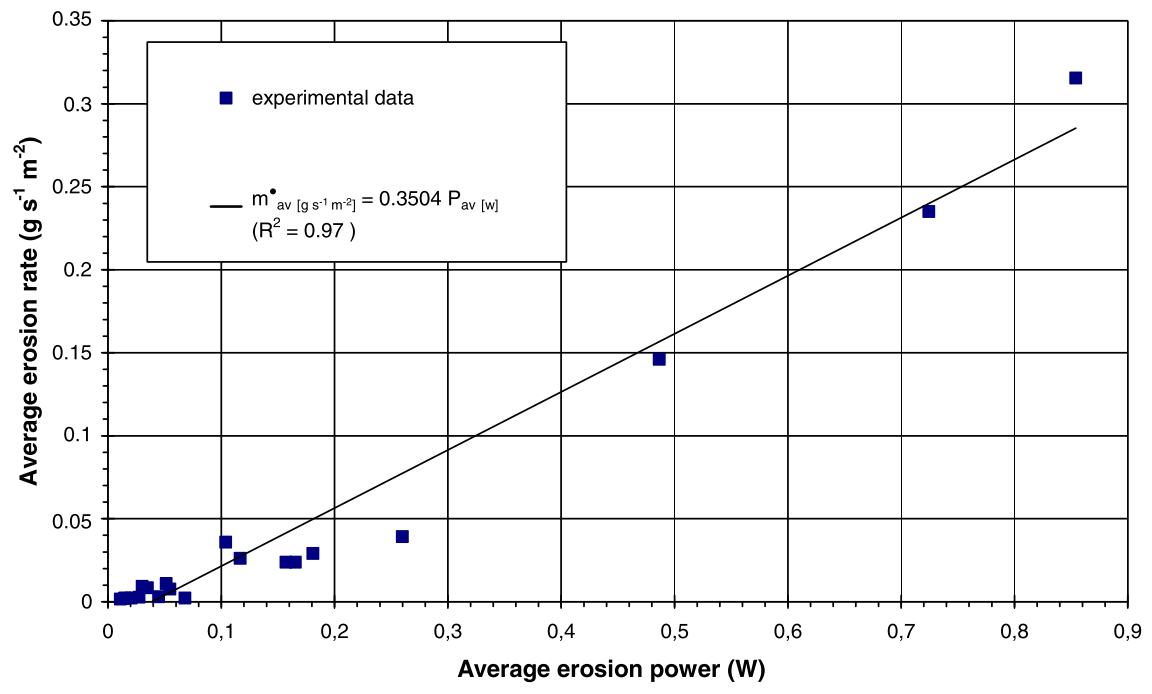

Figure 11. Average erosion rate versus average erosion power. 


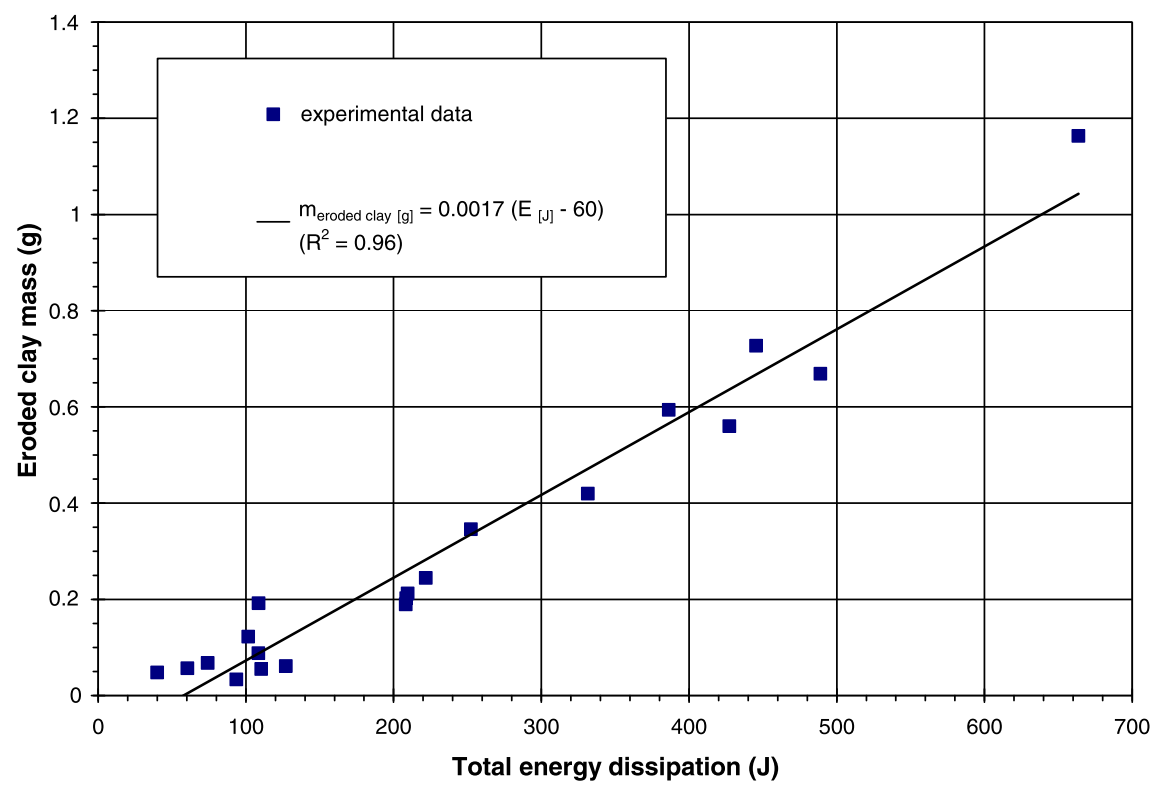

Figure 12. Eroded clay mass versus total energy dissipation.

Thus the average erosion power can be used to estimate the average erosion rate and this estimation does not depend on reduced scale model height.

The total energy dissipated by fluid flow can be determined by integration of the erosion power over the test duration. Figure 12 shows the cumulative eroded clay dry

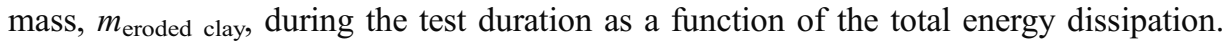

A linear correlation can be expressed between the eroded clay dry mass $m_{\text {erodedclay }}$ (expressed in $\mathrm{g}$ ) and the total energy dissipation $(E$, in $\mathrm{J})$ as:

$$
m_{\text {erodedclay }}=0.0017(E-60)\left(R^{2}=0.96\right)
$$

It can be noted that this correlation does not depend on reduced scale model height, and thus energy analysis may be adopted to avoid any apparent scale effects. So the analysis based on energy dissipation offers the potential for a consistent interpretation of suffusion tests.

According to Equation (27), if total energy dissipation is lower than $60 \mathrm{~J}$ for the tested soil, no significant erosion should be measured. However, for test number 10, characterised by an energy of $40 \mathrm{~J}$, a very small quantity of eroded clay ( $m_{\text {erodedclay }}=0.05 g$ ) was measured. Thus, according to the accuracy of these tests, the critical value of energy seems to be $40 \mathrm{~J}$. These measurements underline the necessity of the definition of a minimal value of eroded clay mass and a corresponding accurate measurement process to definitely characterise erosion initiation.

\section{Conclusion}

A bench has been developed in the IFSTTAR geotechnical centrifuge in order to characterise the sensitivity of clayey sand to suffusion process and to study scale effects. The influence of hydraulic gradient on initiation and development of suffusion is analysed. The characterisation of suffusion depends on the length of the seepage path 
by using the hydraulic gradient concept. The difference in the results is in the magnitude of critical hydraulic gradient and magnitude of erosion rate. For an increase of tested specimen length by a factor 2, the value of critical hydraulic gradient can be multiplied by a factor of 0.6 and rate of erosion can double. This influence of seepage path length may be due to the probability for a detached particle to be filtrated or not. This filtration can induce a clogging and thus a modification of the seepage.

An energy analysis of interstitial fluid has been developed. This analysis leads to a linear correlation between expended power by fluid flow and rate of erosion. By integrating over the time, the eroded clay mass is linearly correlated to the energy dissipation. The suffusion characterisation does not depend on specimen length by using the energy analysis. In comparison with the hydraulic gradient concept, the energy takes into account the potential energy and also the history of the hydraulic loading.

The use of this method for a real structure needs to take into account soil heterogeneities.

\section{Acknowledgements}

The authors thank the Region Pays de la Loire for providing financial support for this work through the R2GC project.

\section{References}

Bendahmane, F., Marot, D., \& Alexis, A. (2008). Experimental parametric study of suffusion and backward erosion. Journal of Geotechnical and Geoenvironmental Engineering (ASCE), 134, $57-67$.

Burenkova, V.V. (1993). Assessement of suffusion in noncohesive and graded soils. In Heibaum \& Schuler (Eds.), Proceedings of the 1st Conference on Geo-Filters (pp. 357-360). Karlsruhe, Germany, Rotterdam, The Netherlands: Balkema.

Corte J.F. (Ed.) (1988). Centrifuge 88. Proceedings of the International Conference on Geotechnical Centrifuge Model, Balkema. Paris, France, 25-27 April.

Fell, R., \& Fry, J.J., (2007). Internal erosion of dams and their foundations. Taylor \& Francis 1995-2012 LAVOISIER S.A.S.

Garnier, J., Gaudin, C., Springman, S.M., Culligan, P.J., Goodings, D., Konig, D., Kutter, B., Phillips, R., Randolph, M.F., \& Thorel, L. (2007). Catalogue of scaling laws and similitude questions in geotechnical centrifuge modelling. International Journal of Physical Modelling in Geotechnics, 7(3), 1-24.

Kenney, T.C., \& Lau, D. (1985). Internal stability of granular filters. Canadian Geotechnical Journal, 22, 215-225.

Kimura, T., Kusakabe, O., \& Takemura, J. (Eds.). (1998). Proceedings of the International Conference Centrifuge 98. Balkema. Tokyo, Japan, 23-25 September.

Ko, H.Y., \& McLean, F. (Eds.) (1991). Proceedings of the International Conference Centrifuge 91. Balkema. Boulder, Colorado, USA, 13-14 June.

Kovacs, G. (1981). Seepage hydraulics. Amsterdam: Elsevier Scientific Publishing.

Leung, C.F.F., Lee, F.H., \& Tan, E.T.S. (Eds.) (1994). Proceedings of the International Conference Centrifuge 94. Balkema. Singapore, 31 August-2 September.

Li, M., (2008). Seepage induced instability in widely graded soils (PhD thesis). University of British Columbia, Vancouver, Canada.

Li, M., \& Fannin, J. (2008). Comparison of two criteria for internal stability of granular soil. Canadian Geotechnical Journal, 45, 1303-1309.

Marot, D., Bendahmane, F., Rosquoet, F., \& Alexis, A. (2009). Internal flow effects on isotropic confined sand-clay mixtures. Soil \& Sediment Contamination, an International Journal., 18, 294-306.

Marot, D., Regazzoni, P.L. \& Wahl, T. (2011). Energy based method for providing soil surface erodibility rankings. Journal of Geotechnical and Geoenvironmental Engineering (ASCE), 137(12), 1290-1294, doi: 10.1061(ASCE)GT.1943-5606.0000538 
Ng C.W.W., Zhang L.M., Wang Y.H. (Eds.), Proceedings of the sixth International Conference on Physical Modelling in Geotechnics. 6th ICPMG'06. Taylor \& Francis. Hong-Kong, 4-6 August 2006.

Phillips, R., Guo, P.J., \& Popescu, R. (2002). Proceedings of the International Conference on Physical Modelling in Geotechnics. ICPMG'02. Balkema. Saint John's, Newfoundland, Canada, 10-12 july 2002 .

Reddi, L.N., Lee, I., \& Bonala, M.V.S. (2000). Comparison of internal and surface erosion using flow pump test on a sand-kaolinite mixture. Geotechnical Testing Journal, 23, 116-122.

Sellmeijer. J.B. (1988). On the mechanism of piping under impervious structures ( $\mathrm{PhD}$ thesis). Delft University of Technology, Netherlands.

Skempton, A.W., \& Brogan, J.M. (1994). Experiments on piping in sandy gravels. Géotechnique, 44, 440-460.

Springman, S., Laue, J., \& Seward, L. (2010). Proceedings of the 7th International Conference on Physical Modelling in Geotechnics. ICPMG'10. Taylor \& Francis Group. Zurich, Switzerland, 28 June-1 July, Zurich.

Wan, C.F., \& Fell, R. (2008). Assessing the potential of internal instability and suffusion in embakment dams and their foundations. Journal of Geotechnical and Geoenvironmental Engineering (ASCE), 134, 401-407.

White, F.M. (1999). Fluid Mechanics (4th ed.). McGraw-Hill Companies Inc. 1221 Avenue of the Americas. New York 10020. 